\title{
Forest History Snapshot: Forest Industry Woodlands Operations Locations Prior to Mergers and Acquistions
}

\author{
Thomas J. Straka \\ School of Agricultural, Forest, and Environmental Sciences, \\ Clemson University, Clemson, USA \\ Email: tstraka@clemson.edu
}

Received September $14^{\text {th }}, 2013$; revised October $15^{\text {th }}, 2013$; accepted October $25^{\text {th }}, 2013$

Copyright (C) 2013 Thomas J. Straka. This is an open access article distributed under the Creative Commons Attribution License, which permits unrestricted use, distribution, and reproduction in any medium, provided the original work is properly cited. In accordance of the Creative Commons Attribution License all Copyrights (C) 2013 are reserved for SCIRP and the owner of the intellectual property Thomas J. Straka. All Copyright (C 2013 are guarded by low and by SCIRP as a guardian.

\begin{abstract}
Forestry industry was a major owner of timberland in the United States over most of the twentieth century This timberland was seen as a cost-effective means to supply their lumber and pulp mills. They were an important owner, with some of the most productive and intensively-managed timberlands in the country. Beginning in the 1980s, other investors realized the value of timberland assets and actively pursued acquisition of the forest products companies and their timberland assets. Mergers and acquisitions were common within the industry as a means to discourage takeovers. These timberlands were traditionally managed by woodlands operations located near the mills. These operations defined classic timber towns, with names like Crossett, Georgetown, Bogalusa, and Millinocket becoming synonymous with the mill and the woodlands. Woodlands operations are nearly extinct as few mills still own timberlands; what might remain is a small wood procurement organization at the same location. These woodlands operations were an important part of forest history and their locations provide much insight into the historical patterns of industrial forest management. Major forest industry woodlands operations are identified by geography and size as a means to record a fading historical artifact of forest history.
\end{abstract}

Keywords: Forest Industry; Woodlands Operations; Woodlands Departments; Locations

\section{Introduction}

The vertically-integrated forest products industry was a major owner of private timberland in the United States over most of the twentieth century (Zinkhan, Sizemore, Mason, \& Ebner, 1992). At the peak of its timberland ownership in the late 1980s and early 1990s, the vertically integrated forest products industry owned nearly 28.5 million ha of timberland in the United States (Block \& Sample, 2001; Sampson, DeCoster, \& Remuzzi, 2000). Today, the industry owns approximately 9 million ha. The forest products industry has divested itself of most of its timberland over the last twenty five years (Gunnoe \& Gellert, 2011). Some of the timberland was spun off as separate entities; real estate investment trusts (REITs) that just held the timberland asset. The four major timberland REITs today (Plum Creek, Weyerhaeuser, Rayonier, and Potlatch) own close to 7 million ha in the United States (Fiacco, 2010; Hickman, 2007). General investors own about 1 million ha of the former forest industry lands (Harris, 2007) and institutional investors, timberland investment management trusts (TIMOs) own approximately 11.5 million ha (Fiacco, 2010; Hickman, 2007; Straka, 2009).

These ownership changes are broad estimates. Transactions are still taking place, some of them very large, and areas owned are constantly changing. It is safe to say that the timberland owned by the vertically-integrated forest products industry has decreased by at least two-thirds and that the trend for divesti- ture of timberland by forest industry is continuing (Stein, 2011). What remains of forest industry are the smaller firms, many of them family-owned. Virtually all of the very large integrated firms are simply gone (Clutter, Mendell, Newman, Wear, \& Greis, 2005; Harris, Baldwin, \& Siry, 2011).

Several trends converged in the 1980s that caused the vertically-integrated forest products companies to divest of their timberlands (Clark \& Howell, 2007). The traditional rationale for holding industrial timberland was future raw material supply (timber supply security), timberland investment return, tax advantages, and some control over the timber costs (Yin, Caulfield, Aronow, \& Harris, 1998). This changed. First, the forest industry firms realized that the security of owning timberland to ensure a constant supply of raw material was an illusion. Ample raw material was available on the open market, including overseas, and often this supply was cheaper than the locally-produced one. Second, TIMOs and REITs were subject to lower tax rates than traditional forest products companies. Much of this timberland was prime for development and these new ownership vehicles provided more profitable ways to develop properties.

The main reasons forest industry sold timberland were 1) the need to increase shareholder returns; 2) the need to reduce debt, especially those firms that acquired other firms with debt financing; 3) firm restructuring to increase tax efficiency using REITs and subchapter S corporations; 4) tax strategies that 
allowed for reduced capital gains taxes; and 5) recognition that timber supply security was not as important as assumed in the past (the market would supply plenty of timber and land could be sold with timber supply agreements for the mills) (Clutter et al., 2005).

Investors in these timberlands saw an asset that 1) produced strong long-term financial returns; 2) had a low correlation with other asset classes (stocks and bonds) and thus reduced overall investment risk; 3) provided a good hedge against inflation; and 4) provided tax advantages (Fasano \& Straka, 2009).

The catalyst was when timberland was identified as an undervalued asset that could be split off from the larger company for a profit (Binkley, 2007). Sir James Goldsmith started the process with the acquisitions of Diamond International and Crown Zellerbach (Clark \& Howell, 2007). By the early 1980s a climate of hostile takeovers emerged and forest industry companies developed defensive strategies like limited partnerships holding the timberland assets (Binkley et al., 1996).

The rise of TIMOs also started in the 1970s with several pension funds diversifying into timberland investments (Binkley, 2007). The TIMO provided the acquisition and management services for portfolios of timberland for large institutional investors (like pension funds and insurance companies). At the same time some forest product companies divested of their timberland, putting it into subsidiaries that traded separately. Tax advantages also favored those that had timberland in separate real estate investment trusts (REITs). Both trends combined to separate timberland from the forest products companies (Irland, 2005). By the 1980s the transition to TIMO ownership from forest industry land or conversion of forest industry land to REITS was in full swing.

Changes in tax laws fueled industry divesting of timberland. The Employee Retirement Income Security Act of 1974 (ERISA) encouraged pension funds to invest in timberland (Binkley, 2007) and the 1986 Tax Reform Act removed a capital gains tax advantage for industrial ownership (Yin et al., 1998). Irland and Howard (1989) saw the increased activity in timberland ownership exchange resulting from issues like fiber supply control, timberland as collateral, timberland for investment, and timberland as a source of capital. As this transition played out, several major mergers and acquisitions took place in the industry (Diamond et al., 1999). Timberland emerged as an attractive nontraditional asset class.

By 1982 the first institutional investment in forest industry timberland began (Fu, 2012). Today, none of the larger traditional woodlands operations exist. A few of the smaller ones still exist (for now). The geographical locations of these operations correspond to the general location of forest industry timberlands. Woodlands operations are described in terms of size (timberland area owned) and location. This presents an historical perspective of where forest industry operated and where the "timber towns" used to be located. Forest industry had a huge impact on American development and these locations continue to have significant historical ties to the former dominant forest products industry.

\section{Woodlands Operations}

What was the traditional woodlands operation? It was the operational management unit for a large block or area of timberland. It represented the forest management structure for administering that large area of timberland. The structure tended to be decentralized with managerial authority radiating out to area offices and down to district offices. A woodlands operation could be small (perhaps 20,000 ha) to very large (perhaps 400,000 ha). Obviously, decentralization had to increase with overall size. Each operation had a headquarters office, for logistical reasons often located centrally to the timberland, that would report to a corporate or division headquarters.

American forestry has Central European roots and a strong administrative structure has always been a starting point in forest management. The earliest texts centered on a German framework of central control (Recknagel, 1913). An entire section of an early forest management textbook was devoted to forest organization (Chapman, 1931), with chapters devoted to subjects like principles of forest organization, evolution of forest organization, organization of a large forest enterprise, acquisition and consolidation of forests, boundaries, the coordination of land uses, the subdivisions of the forest area, and plans for development of the forest. Woodland operations tended to be very similar in appearance and structure; this was not a coincidence. Foresters were taught organizational structure from the same textbooks and differences were few. Modern forest management textbooks do not devote the same amount of space to the subject of forest organization, but it is still covered and the administrative framework has not changed from the early forestry development periods (Bettinger, Boston, Siry, \& Grebner, 2009).

Industrial owners of timberland tend to be profit-motivated and usually develop extensive forest resource management plans for their resources (Davis, Johnson, Bettinger, \& Howard, 2001: pp. 22-24; Leuschner, 1984: p. 256). Meyer, Recknagel, Stevenson, \& Bartoo (1961: pp. 180-200) describe the forest as a business enterprise and illustrate the various function of a typical woodlands operation. The earlier textbooks were very detailed on setting up administrative structure, as it was a task that was a very current need. Chapman (1931: pp. 196-212) presented details on the subdivisions of the forest area, including administrative subdivisions, blocks, logging units, compartments, and subcompartments. These components comprise a woodlands operation. Chapman (1931: p. 198) explains there is an optimal size for a woodlands operation: "The administrative problem which such subdivisions seek to solve is the dual one of coordinating all the field work of a large organization while decentralizing it as much as possible. This result is accomplished by giving subordinate executives all the responsibility they can bear and depending on inspection to see the work is properly conducted. The size of the administrative unit has a direct bearing on the whole problem, as it must be adjusted to the volume and character of the business to be transacted within the area”.

Davis (1966: pp. 247-261) described forest organization and subdivision. While he does not call his organization a woodlands operation, that is what he is describing. Davis (1966: pp. 248-249) discusses the factors influencing forest organization and subdivision: 1) establishment and maintenance of land ownership, 2) future acquisition plans, 3) scope and character of work to be done, 4) work load and supervision, 5) marketing area, 6) topography, 7) transportation facilities, 8) character of the forest, and 9) inventory and recordkeeping needs.

Davis (1966: pp. 252-253) presents organization charts for two typical large forest products organizations, one in the southeastern Unites States and one in the Lake States of the US 
Both are headed by a Woodlands Manager, with an assistant manager and administrative assistants. The southeastern operation has a land department (with a nursery supervisor, equipment supervisor, and survey engineer) and a wood procurement department (with superintendents and field representatives). Plus, the southeastern woodlands operation has a technical department (forest inventories, research, and cruising and acquisition control) and conservation (public relations) department. The Lake States woodlands operation has a chief forester (forest management, silviculture, acquisition, inventory, wood quality and scaling, forest engineering, nursery, and forest pest problems). In addition, the Lake States operation has a production superintendent (with district foresters responsible for both land management and wood procurement), a forest products (marketing) manger, and a plant and equipment superintendent. Careful analysis of the various job functions will show both organizations accomplish exactly the same tasks.

Davis (1966: p. 254) summarizes what goes into the selection of a woodlands operation organization, size, and location: "a number of factors influence the size and character of field units. Work load and the kind of total organization are two of them. Also important are such things as an areas that be efficiently administered from a field headquarters without excessive time spent in travel, the need for the forest manager to become closely familiar with the forest, the location of schools and other urban services, and living and housing considerations for personnel". He summarizes the selection as: "The primary consideration is to get the job done efficiently".

These were the considerations that went into development and location of woodlands operations. Note that many had wood procurement departments attached or integrated into the woodlands department. The mills may have sold the timberland and gotten rid of the woodlands operations, but many retained the wood procurement operations. Thus, many of these locations still have timber-related operations. Many don't. That is just part of the interesting history of this large forest products industry transition.

\section{Geography of the American Forest}

Geography plays a large role in determining the locations of woodlands operations. Many operational factors were just discussed that impact location. But there is one large factor that breaks the operations into large geographical regions. The American forest based on tree species and forest composition is broken into a northern, southern, and western forest. Latitude divides the northern and southern forest, with the Appalachian Mountains allowing some northern tree species to expand their range into the South. The Great Plains separate the eastern and western forests. Then commercial factors like transportation costs, markets, geographical barriers (the Great Lakes, for example), natural transportation routes (the Mississippi River and the Great Lakes again), and native tree species further define the geographical regions of these operations. Generally, one can break the forest/woodlands regions into the Northeast or North, Lake States (Upper Michigan, Wisconsin, and Minnesota), the South (including east Texas and Oklahoma), and the West (with most the timber being in the Pacific Northwest).

Figure 1 illustrates the natural pattern just described. The northern and southern forest shows up quite well, with the darker Appalachian Mountain hardwood forests extending into the South. The Lake State forests stand out well and the western forests show the large timber volumes in the Pacific Northwest. Woodlands operations will be characterized as northern, southern, Lake States, or western.

Figure 2 illustrates the pattern of industrial timberland holdings in the contiguous United States. The northern, southern, Lake States, and western forests are even more obvious on this map. The Lake States timberlands are quite distinct. Western timberlands are also distinct, even the concentration of timberland in the Pacific Northwest stands out. The eastern timberland is distinct, but the division between north and south is not obvious. It is generally based on "northern" and "southern" tree species. The historical Mason-Dixon line is a logical place to divide the two. The southern border of Pennsylvania is part of that line. Detailed maps and data analysis is available from the United States Department of Agriculture (USDA) Forest Service, Forest Inventory and Analysis. Much of it is produced to support the Forest and Rangeland Renewable Resources Planning Act (RPA) of 1974 that requires periodic analysis and reports on the nation's forest resources (Smith, Miles, Perry, \& Pugh, 2009).

The most recent RPA data does not break out the industrial timberland. It uses a category of private corporate that includes all timberland administered by entities that are legally incorporated. Of course, that includes forest industry lands. REITs are also incorporated. TIMOs and many other types of forest holdings are also incorporated. Much of the old forest industry land is still in this category, as it moved from incorporated forest industry land to incorporated other timberland. The breakdown of private corporate land provides insight into timberland ownership. Table 1 shows timberland area breakdown by region, giving an indication of where woodlands operations would be expected.

Based on Table 1 most of the woodland operations ought to be in the South with just over half the timberland area. That will be shown not to be the case. Many firms decided to locate a woodlands operation in each forest region, even if some operations did not administer large areas. Many factors came into play in determining location, not just the timber resource. If one was to plot the locations of woodlands operations, the map would look similar to Figure 2. The location decision involved a tradeoff. Mill location and timber location drove the decision, but part of the function was wood procurement. So there was an advantage in not being located too close to competitors (so there would be less competition for outside wood). These location decisions were complex and often the optimal location was not the choice that seemed to make sense at first.

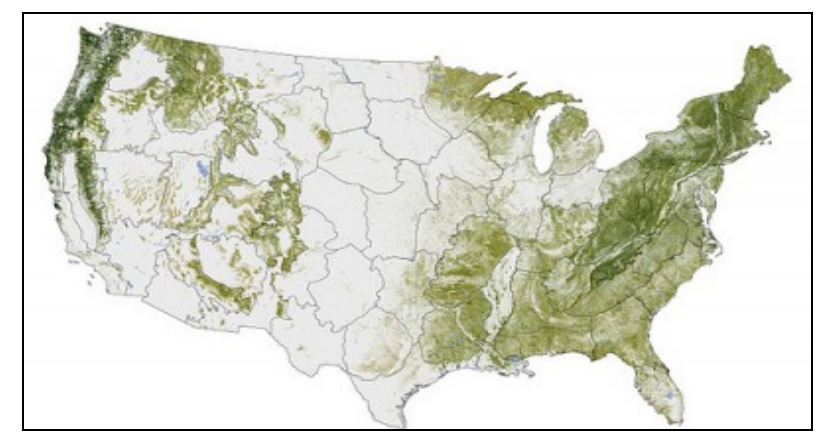

Figure 1.

Woody biomass, contiguous United States, 2012 (NASA Earth Observatory). 


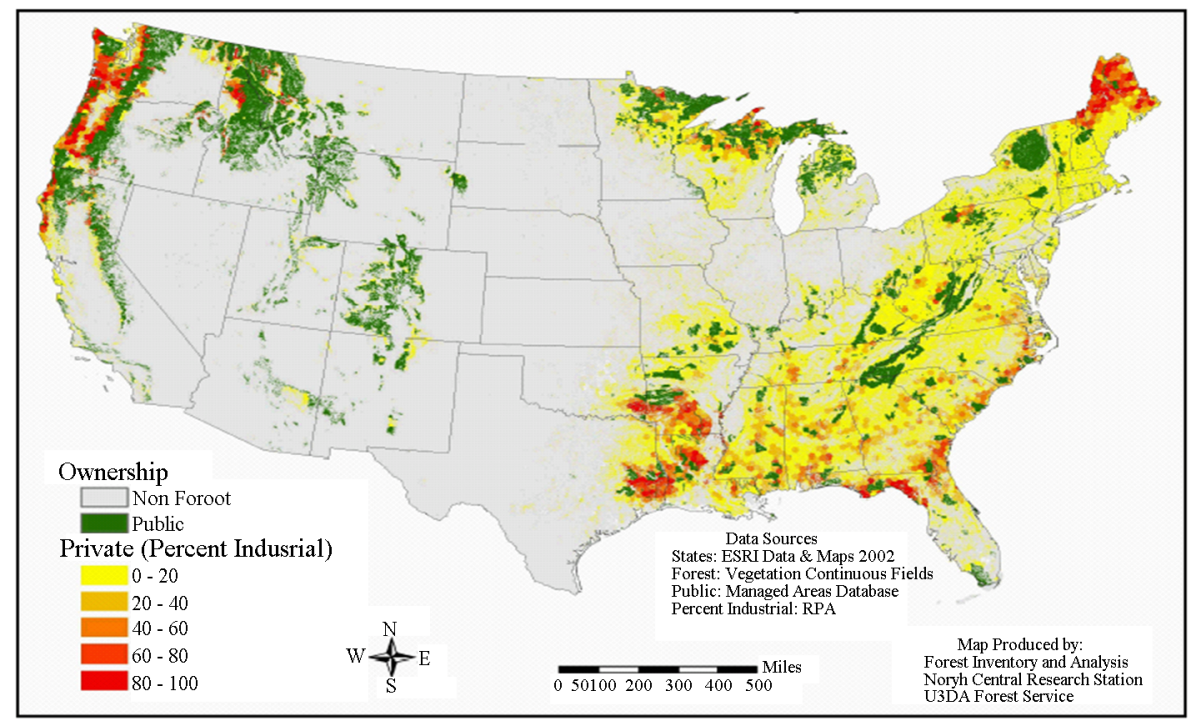

Figure 2.

Industrial timberland in United States, 2002 (USDA Forest Service, Forest Inventory and Analysis).

Table 1.

Private corporate timberland in United States by region, 2007 (Smith, Miles, Perry, \& Pugh, 2009: pp. 192-194).

\begin{tabular}{ccc}
\hline Region & Timberland ha (area) & Percent of timberland \\
\hline North & $9,283,000$ & 5 \\
South & $23,067,000$ & 21 \\
Lake States & $2,112,000$ & 54 \\
West & $8,487,000$ & 20 \\
\hline
\end{tabular}

\section{Woodlands Operations Locations}

Timber Harvesting Magazine published a Wood \& Woodlands Directory/Loggers’ Buying Guide. The directory included most of the major woodlands divisions that operated in the United States. The directory was "a listing of personnel employed by the wood supply and forest management organizations of the nation's major industrial timber companies" (Timber Harvesting, various dates). The list of locations developed below came from this directory. The fifteen years from 1980 to 1994 were chosen as representative of the peak of the forest products industry and those fifteen directories were used to develop the listing.

There are multiple ways to organize the data. Size makes much sense and the listings will be by size, with the larges operations first. Within size grouping, the largest operations will be presented first. The directory did not include timberland areas owned. O’Laughlin \& Ellefson (1982: p. 785) was the basis of all timberland area statistics.

\section{Operations Managing 1,000,000 ha or More}

These are the large multi-national corporations with huge timberland holdings backing major lumber, plywood, and pulp and paper mills. They tend to have a major corporate headquarters, often in New York City or nearby; Atlanta, Georgia and Portland, Oregon are also major headquarter cites. Timber- lands and wood products tend to be a major division of the corporation and usually very large regional timberland divisions are established. Divisions tend to be organized geographically (Northeast, Midwest, Southeast, South Central, Rocky Mountain, and Pacific Northwest), by wood product (lumber, plywood, pulp and paper), or by historical ownership patterns (a division might be a purchased lumber company).

International Paper listed its corporate headquarters as New York in 1980 and its timberland area was 2,877,315 ha. It had Woodlands and Wood Products Operation headquartered at Mobile, AL, Dallas TX, and Memphis, TN. Woodlands operations were located at: Georgetown, SC; Natchez, MS; Camden, AR; Shreveport, LA; Augusta, ME; and Portland, OR. Over the fifteen years Erie, PA; Jackson, MS; and Gardiner, OR were added.

Weyerhaeuser Company listed its corporate headquarters as Tacoma Way, WA and its timberland area was 2,142,001 ha. They listed three land and timber regions centered at Columbus, MS; Mountain Pine, AR; and New Bern, NC; Wright City, OK; and Hot Spring, AR; and Tacoma, WA. Timber Harvesting Magazine was a southern magazine and some very western companies like Weyerhaeuser did not supply much data for their western operations.

Georgia-Pacific Corporation first listed its corporate headquarters as Portland, OR, but by the 1983 directory it was listed as Atlanta, GA. Its timberland area was 1,671,352 ha. In 1980 in the South they had two major divisions, one at Crossett, AR and one at Augusta, GA. The Crossett Division was broken into smaller timber operations in Arkansas and Mississippi. The Southern Division was broken into a Northern Timber Group at Alcolu, SC and a Southern Timber Group at Pine Mountain, GA. Other woodlands operations were at Bellingham, WA; Coos Bay, OR; Eugene, OR; Lyons Falls, NY; Fort Bragg, CA; Zachary, LA; Woodland, ME; and Toledo, OR. They also owned Hudson Pulp \& Paper Corporation at Palatka, FL. Fifteen years later, after acquisitions and reorganizations, Georgia-Pacific's woodlands operations were at Woodland, ME; Wendell, NC; Watkinsville, GA; Cedar Springs, GA; Bruns- 
wick, GA; Palatka, FL; Jackson, MS; and Crossett, AR.

St. Regis Paper Company listed its headquarters as New York and its timberland area was 1,286,496 ha. St. Regis had a Northern Timberlands Division at Bangor, ME and a Southern Timberlands Division at Jacksonville, FL, plus a Lumber and Plywood Division at Tacoma, WA. The northern region had regional timberlands at Deferiet, NY; Rhinelander, WI; and Bucksport, ME. The southern division had regional timberlands at Jacksonville, FL; Pensacola, FL; Monticello, MS; and Lufkin, TX. They later added a Minnesota Region with operations at Bemidji, MN. By 1986 St. Regis was no longer in the directory.

Champion International Corporation was listed as headquartered at Stamford, CT and its timberland area was 1,216,889 ha. Champion International had a Gulf States Operation at Huntsville, TX; a Southeastern Operations at Greenville, SC; a West Coast Operations at Eugene, OR; a Rocky Mountain Operations at Missoula, MT; and a Lake States Operation at Norway, MI. By 1994 there was a Northern Timberlands at Bangor, ME; a Southern Timberlands at Greenville, SC; a Western Timberlands at Huntsville, TX; with a Technical Center in Jacksonville, FL.

Great Northern Nekoosa Corporation was listed in 1980 as owning 1,097,507 ha of timberland. It was operated as two divisions and a subsidiary (McCann 1994). Paper company mergers began well before the 1980s. In 1965 Great Southern Paper Company was merged into Great Northern Paper (Lehman Brother Special Collection, 2013) and in 1970 Great Northern Nekoosa was formed by the merger of Nekoosa Edwards Paper Company and Great Northern Paper Company (Steeves, 2009). The directory always listed Great Northern Nekoosa as two separate woodlands: Great Northern Paper Company at Millinocket, ME and Great Sothern Paper Company at Cedar Springs, GA. Nekoosa Papers Inc. was listed with a northern woodlands at Port Edwards, WI and a Southern Woodlands at Ashdown, AR.

Boise Cascade Corporation was headquartered in Boise, ID and owned 1,068,370 ha of timberland. Its Timber and Wood Products Group had a Southern Idaho Region at Emmett, ID; a Northeast Oregon Region at La Grande, OR; a Northwest Oregon Region at Monmouth, OR; a Southern Oregon Region at Medford, OR; a Northeast Washington Region at Kettle Falls, WA; a Central Washington Region at Yakima, WA; a South Atlantic Region at Moncure, NC; a Southeast Timberlands at Florence, SC; and a Midwest Woodlands at International Falls, MN. Boise Cascade also had an operation at DeRidder, LA called Boise Southern Company. By 1994 the Southeast Timberlands was listed at Charlotte, NC and there was a Rumford Mill Wood Department listed at Rumford, ME.

\section{Operations Managing 1,000,000 to 500,000 ha}

These were still large timberland operations and were often organized similar to the very largest firms. However, most had perhaps two divisions, often geographically based (northern and southern, southern and western, or northern and western). They are big enough to have product divisions. Often the corporate headquarters was at the larger or older of the two divisions. Some were located in a single geographical area. These firms tend to be fairly similar to the larger companies in terms of organization.

Scott Paper Company listed its headquarters as Philadelphia, PA and its timberland area was 743,812 ha. Scott had a North- east Operations at Winslow, ME and a Southern Operations at Mobile, AL. S.D. Warren was listed as a division of Scott Paper with a Timberlands Division at Fairfield, ME.

Crown Zellerbach Corporation was headquartered at Portland, OR and had a timberland area of 703,748 ha. It Northwest operations were managed out of Portland, OR and its Southern operations were managed out of Bogalusa, LA. Crown Zellerbach was one of the early take-over targets.

Union Camp Corporation listed Woodlands Division headquarters as Savannah, GA and its timberland area was 696,869 ha. Union Camp had a Georgia Region at Savannah, GA: A Virginia Region at Franklin, VA; an Alabama Region at Montgomery, AL; and a South Carolina Region at Eastover, SC.

In 1980, Time Inc., the magazine publisher, owned two forest products companies: Temple-Eastex Inc. and Inland Container Corporation, with a combined timberland area of 619,169 ha. Temple-Eastex was managed out of Diboll, TX, with an Eastex Division in Silsbee, TX. Inland Container was managed out of New Johnsonville, TN. Time spun off the companies and they became Temple-Inland Inc.

Burlington Northern Inc. had a Timber and Land Department at Seattle, WA and listed its timberland area as 603,791 ha. The department managed timberland in OR, WA, ID, and MT and sold logs and stumpage on the open market.

The Continental Group (Continental Forest Industries) had a Woodlands Division in Savannah, GA and listed its timberland area as 595,697 ha. Continental had a Savannah District at Savannah, GA; an Augusta Division at Augusta, GA; a Hodge Division at Hodge, LA; and a Hopewell Division at Hopewell, VA.

Diamond International Corporation listed its timberland area as 588,008 ha. It had a New England Land and Timber Division managed out of Old Town, ME, with a Maine Woodlands at Old Town; A New Hampshire Woodlands at Groveton, NH; a Minnesota Woodlands at Cloquet, MN; and a New York Woodlands at Plattsburg, NY. It also had a California Timber and Lands Division at Red Bluff, CA. Diamond International was one of the early takeover targets.

The Mead Corporation had its headquarters in Dayton, $\mathrm{OH}$ and listed its timberland area as 547,135 ha. Mead had Woodland Divisions at Chillicothe, OH; Stevenson, AL; Kingsport, TN; Escanaba, MI; and South Range, MI.

Potlatch Corporation is headquartered in Spokane, WA and listed its timberland area as 530,543 ha. It had a Northwest Division at Cloquet, MN; a Southern Division at Warren, AR; and a Western Division at Lewiston, ID.

\section{Operations Managing 500,000 to 200,000 ha}

These are the medium-sized firms. Most occupy a single region, rarely more than two regions. There tends to be a single timberlands division. Sometimes small geographical divisions are established within one geographical region. These companies were still major forestry/timberlands operations within their region; they just tended not to have a national focus. Much innovation came from these mid-sized firms.

Westvaco Corporation was headquartered at New York, NY and listed its timberland area as 494,121 ha. The Timberlands Division was headquartered at Summerville, SC. The Southern Woodlands was at Summerville, SC; the Virginia Woodlands was at Appomattox, VA; the West Virginia Woodlands was at Rupert, WV; and the Central Woodlands was at Wickliffe, KY. 
ITT Rayonier Incorporated had a Southeast Timber Division headquartered at Fernandina Beach, FL and listed its timberland area as 433,823 ha. It had a Florida Operation Office at Fernandina Beach, FL and a Georgia Operations Office at Jesup, GA. They also had a Baxley Lumber Division at Baxley, GA.

Owens-Illinois, Inc. has a Forest Products Division managed out of Toledo, $\mathrm{OH}$ and listed a timberland area of 405,090 ha. They had a Northern Woodlands at Tomahawk, WI; a Southern Woodlands at Valdosta, GA; an Eastern Woodlands at Big Island, VA; and a Western Woodlands at Orange, TX.

Louisiana-Pacific Corporation was headquartered at Portland, OR and listed a timberland area of 356,123 ha. It had division offices in Beaverton, OR; Antioch, CA, Coeur D'Alene, ID; Samoa, CA; Escanaba, MI; Red Bluff, CA; Standard, CA; New Waverly, TX; and Ukiah, CA. They also owned Ketchikan Pulp Company at Ketchikan, AK. Later it had just a Western Division office at Samoa, CA and a Northern Division office in Hayden Lake, ID.

Container Corporation of America, owned by Mobil Corporation, listed its timberland area as 310,394 ha. It had two Timber Departments, one at Brewton, AL and one at Fernandina Beach, FL.

Kirby Forest Industries, Inc., owned by Santa Fe Southern Pacific Corporation, listed its timberland area as 264,664 ha. Its Woodlands Division was in Houston, TX and later at Silsbee, TX. Manville Forest Products Corporation (subsidiary of Johns Manville; Olinkraft) was headquartered at West Monroe, LA and listed its timberland area as 236,336 ha. The woodlands were managed out of West Monroe. Kimberly-Clark Corporation had a Division Headquarters at Coosa Pines, AL and listed a timberland area of 227,029 ha. Its woodlands were managed out of Coosa Pines and Waynesboro, GA.

Willamette Industries, Inc. was headquartered at Portland, OR and listed its timberland area as 221,768 ha. It had woodlands operations at Albany, OR: Ruston, LA; Campti, LA; Hawesville, KY; Centerville, TN; Bennettsville, SC; and Johnsonburg, PA. American Can Company listed its timberland area as 202,343 ha. It had a Lake States Woodlands at Green Bay, WI and a Southern Woodlands and Sawmills at Butler, AL. Masonite Corporation had a Fiberboard Division headquartered at Spring Hope, NC and listed a timberlands area of 201,129 ha. There was a Woodlands Division at Spring Hope plus a Southern Woodlands at Laurel, MS and a Western Lumber Division at Calpella, CA.

\section{Operations Managing Less than 200,000 ha}

While these were the smallest of the forest products companies, concentrated timberland area in small regions could create some relatively large single landholdings. But, in general, these were smaller timberlands, most always associated with a region or sub-region. All of these were large enough to be generally well-known in the forestry community.

Southwest Forest Industries had a Rocky Mountain Resources Division managed out of Flagstaff, AZ and listed its timberland area as 185,346 ha. Sierra Pacific Industries listed a timberlands area of 182,189 ha and was managed out of Arcata, CA. Packaging Corporation of America (owned by Tenneco) listed its timberland area as 169,563 ha and it had divisions in Filer City, MI and Counce, TN. Longview Fibre Company was headquartered out of Longview, WA and listed its timberland area as 165,112 ha. The woodlands were managed out of Long- view.

Hammermill Paper Company had a Timberlands and Forest Products Divison at Erie, PA and listed its timberland area as 162,279 ha. It managed American Hardwood Industries, Inc. at Union City, PA; Amos-Hill Veneer \& Lumber Company at Edinburg, IN; Frank Purcell Lumber Company at Kansas City, KS; Hammermill Hardwoods at Augusta, GA; a Northern Timber Division at Erie, PA; a Southern Timberlands Division at Selma, AL; and a Southern Forest Products Division at Selma, AL.

Federal Paper Board Company had a Riegelwood Operations at Bolton, NC and listed a timberland area of 100,768 ha. The woodlands were managed out of Bolton. Bendix Forest Products Corporation was headquartered at San Francisco, CA and listed its timberland area as 69,201 ha. The woodlands were managed out of San Francisco. The Pacific Lumber Company was headquartered at Scotia, CA and its timberland area is listed as 66,773 ha and its woodlands are managed out of Scotia.

Pope \& Talbot, Inc. was headquartered in Portland, OR and has a listed timberland area of 52,609 ha. Medford Corporation had its headquarters in Medford, OR and listed its timberland areas as 35,612 ha. Arcata Redwood Company had a woodlands division in Humboldt County, CA and listed its timberland area as 30,756 ha. Bohemia Lumber Company was headquartered at Eugene, OR and had woodlands in Oregon and Northern California. Its timberland area was 28,328 ha.

Other woodlands operations were too small in timberland area to be listed in the O’Laughlin \& Ellefson (1982 summary. They were still large enough to be listed in the woodlands directory. They were Abitibi Corporation at Alpena, MI and Roaring River, NC; Alabama River Woodlands, Inc. at Monroeville, AL; Allied Paper Incorporated at Jackson, AL; Alton Box Board Company at Jacksonville, FL; Appleton Papers Inc. at Combined Locks, WI; Arkansas Kraft Corporation at Morrilton, AR; Armstrong Cork Company at Macon, GA; Badger Paper Mills, Inc. at Peshtigo, WI; Bear Island Paper Company at Ashland, VA; Blandin Paper Company at Grand Rapids, MI; Bowater Incorporated with woodlands in Catawba, SC and Calhoun, TN; Brooks-Scanlon, Inc. at Bend, OR (with 93,482 ha); Brown Company at Berlin, NH; Brunswick Pulp Land Company at Brunswick, GA; The Buckeye Cellulose Corporation at Perry, FL; The Chesapeake Corporation of Virginia at West Point, VA; Chessie Resources, Inc. at Huntington, WV; The Cleveland-Cliffs Iron Company at Iron Mountain, MI; Coastal Lumber Company at Weldon, NC; Consolidated Papers, Inc. at Wisconsin Rapids, WI; Coos Head Timber Company at Coos Bay, OR and Dead River Company at Bangor, ME.

Other smaller woodlands were Finch, Pruyn \& Company, Inc. at Glens Falls, NY; Flambeau Paper Corporation at Park Falls, WI; Georgia Kraft Company at Coosa, GA; Georgia Timberlands Inc. at Atlanta, GA; Gilman Paper Company at St. Marys, GA; The Glatfelter Pulp Wood Company at Spring Grove, PA; Green Bay Packaging Inc. at Green Bay, WI; Gulf States Paper Corporation at Tuscaloosa, AL; Hemphill-O’Neill Lumber Company, Inc. at Chehalis, WA; Interstate Paper Corporation at Riceboro, GA; Kaibab Industries at Phoenix, AZ; The Langdale Company at Valdosta, GA; Leaf river Forest Products, Inc. at New Augusta, MS; MacMillan Bloedel Inc. at Pine Hill, AL; Menasha Corporation at Otsego, MI; and Mosinee Paper Corporation at Mosinee, WI.

Other smaller woodlands were Pineville Kraft Corporation at 
Pineville, LA; Pope \& Talbot, Inc. at Portland, OR; Prentiss \& Carlisle Company at Bangor, ME; The Proctor and Gamble Paper Products Company at Green Bay, WI; Publishers Paper Company at Oregon City, OR; St. Joe Paper Company at Port St. Joe, FL; Saunders Brothers at Westbrook, ME; Simpson Timber Company at Seattle, WA; Stilley Plywood Company at Conway, SC; Sonoco Forest Products at Hartsville, SC; South Carolina Industries, Inc. at Florence, SC; Stone Container Corporation at Columbia, SC; Texasgulf Inc. at Johnsonburg, PA; Thilmany Pulp and Paper Company at Kaukauna, WI; Vancouver Plywood Company at Florien, LA; Virginia Fibre Corporation at Amherst, VA; Wausau Paper Mills Company at Brokaw, WI: and W-I Forest Products, Inc. at Dinuba, CA with a timberland area of 72,843 ha.

\section{Conclusion}

Woodlands Divisions locations followed a very distinctive pattern. Divison locations listed were plotted on a map of the United States, producing a map that was not very usable. Division locations tended to be in clusters that produced a muddled, difficult-to-read map. Figure 2 with does a better job of giving a general geographical perspective on location.

Several general observations are apparent. As one would expect Woodlands Divisions were located near the mills. Since the timberlands tends to be close to the mills, and the divisions close to the timberlands, that relationship follows common sense. The headquarters of the Woodlands Division, at least, would be close to the mills. Of course, some timberlands were spread out over fairly vast areas. Woodlands then would have some sort of regional pattern based on minimizing transportation and travel costs. Woodland Divisions (not the headquarters, but the operational first-level subdivisional level) would manage a timberland area of 20,000 to 100,000 ha. The lower end would be for smaller woodlands with limited area. The upper end would be very large woodlands with very large subdivisions.

National firms with timberland managed across the country usually had regional woodlands based on the North and South in the eastern United States, with the Midwest or Lake States usually managed separately. Eastern and Western Divisions were almost always the case, due to the large differences in timber types, logging conditions, and customs. Companies with large ownerships in the South usually managed them as a Southeastern Division and a Mid-South Division.

There is one strong influence on location that is not apparent from just studying the map and mill locations. Historical development of the industry has much influence on division location. For example, the pulp and paper industry developed in certain parts of the Northeast and Midwest. Those locations tended to have Woodlands Divisions. Many of the very early lumber companies with reasonably large timberlands were bought up by the larger firms. Crossett, AR; Georgetown, SC; Brunswick, GA; and Brewton, AL were early lumber mill towns. So history has aided in aligning these division locations.

Most of these Woodland Divisions no longer exist. However, the same factors that influenced how the locations were first selected and historical development have tended to encourage the TIMOs and REITs that acquired the timberlands to maintain operations offices at these same locations. While Woodlands Divisions were operational offices that directed large organizations that managed the trees on the ground, these new divisions are more managerial offices, with the field work usually contracted out to consulting forestry organizations. Locations have only changed moderately, but function is very much different.

The history of these locations is an important part of forest history and reveals much about management of the nation's private forest resource over the twentieth century. It tells a story of how forest management was organized and where forest industry was strongest. Timber was a vital natural resource that was crucial to the nation's development. Its history helps tell the history of the nation.

\section{REFERENCES}

Bettinger, P., Boston, K., Siry, J. P., \& Grebner, D. L. (2009). Forest management and planning. Burlington, MA: Academic Press.

Binkley, C. S. (2007). The rise and fall of the timberland investment management organizations: Ownership changes in US forestland. In 2007 Pinchot Distinguished Lecture. Washington, DC: Pinchot Institute for Conservation.

Binkley, C. S., Raper, C. F., \& Washburn, C. L. (1996). Institutional ownership of US timberland: History, rationale, and implication for forest management. Journal of Forestry, 94, 21-28.

Block, N. E., \& Sample, V. A. (2001). Industrial timberland divestitures and investment: Opportunities and challenges in forest conservation. Washington, DC: Pinchot Institute for Conservation.

Chapman, H. H. (1931). Forest management. Albany, NY: J. B. Lyon Company, Publishers.

Clark, S. A., \& Howell, P. (2007). From Diamond International to Plum Creek: The era of large landscape conservation in the Northern Forest. Maine Policy Review, 16.2, 56-65.

Clutter, M., Mendell, B., Newman, D., Wear, D., \& Greis, J. (2005). Strategic factors driving timberland ownership changes in the U.S. South. Athens, GA: Center for Forest Business, University of Georgia; USDA Forest Service; Southern Group of State Foresters.

Diamond, J., Chappelle, D. E., \& Edwards, J. D. (1999). Mergers and acquisitions in the forest products industry. Forest Products Journal, 49, 24-36.

Davis, K. P. (1966). Forest management: Regulation and valuation (2nd ed.). New York, NY: McGraw-Hill Book Company.

Davis, L. S., Johnson, K. N., Bettinger, P., \& Howard, T. E. (2001). Forest management: To sustain ecological, economic, and social value (4th ed.). Long Grove, IL: Waveland Press, Inc.

Fiacco, J. B. (2010). A brief TIMO backgrounder. Summerville, SC: Timberland Strategies, LLC.

Fu, C. (2012). Timberland investments: A primer. Brookline, MA: Timberland Investment Resources.

Gunnoe, A., \& Gellert, P. K. (2011). Financialization, shareholder value, and the transformation of timberland ownership in the US. Critical Sociology, 7, 265-284.

Harris, T. (2007). Industry, TIMOs, REITs, the changing face of forestry: The new private forest landowners. Forest Landowner, 66, 3-5.

Harris, T., Baldwin, S., \& Siry, J. (2011). United States timberland markets: Transactions, values and market research. Athens, GA: Timber Mart-South.

Hickman, C. (2007). TIMOs and REITs. Washington, DC: USDA Forest Service, Research and Development.

Irland, L. C. (2005). U.S. forest ownership: historical and global perspective. Maine Policy Review, 14.1, 16-22.

Irland, L. C., \& Howard, T. E. (1989). Innovative forms of timberland ownership: What are the driving forces? The Consultant, 34, 32-37.

Lehman Brothers Collection (2013). Great Northern Nekoosa Corporation. Boston, MA: Harvard University, Harvard Baker Library Special Collections.

Leuschner, W. A. (1984). Introduction to forest resource management. New York, NY: John Wiley \& Sons, Inc.

McCann, P. K. (1994). Timber! The fall of Maine's paper giant... A chronicle of Great Northern paper Company in the 1980s and 1990s. Ellsworth, ME: The Ellsworth American.

Meyer, H. A., Recknagel, A. B., Stevenson, D. D., \& Bartoo, R. A. 


\section{T. J. STRAKA}

(1961). Forest management (2nd ed.). New York, NY: The Ronald Press Company.

O’Laughlin, J., \& Ellefson, P. V. (1982). Strategies for corporate timberland ownership and management. Journal of Forestry, 80, 784791.

Recknagel, A. B. (1913). The theory and practice of working plans (forest organization). New York, NY: John Wiley \& Sons.

Sampson, N., DeCoster, L., \& Remuzzi, J. (2000). Changes in forest industry timberland ownership: 1979-2000. Alexandria, VA: The Sampson Group, Inc.

Smith, W. B., Miles, P. D., Perry, C. H., \& Pugh, S. A. (2009). Forest resources of the United States, 2007 (General Technical Report WO78). Washington, DC: United States Department of Agriculture, Forest Service.

Steeves, B. H. (2009). Special Collections: Guide to the Great Northern Paper Company records, history. Orono, ME: University of Maine,
Raymond H. Fogler Library.

Stein, P. R. (2011). Trends in forestland: Ownership and conservation. Forest History Today, Spring/Fall, 2011, 83-86.

Straka, T. J. (2009). Does your client own timberland? Financial Advisor, 10, 95-96.

Timber Harvesting (1980-1994). Wood and woodland directory. Montgomery, AL: Hatton-Brown Publishers, Inc.

Yin, R., Caulfield, J. P., Aronow, M. E., \& Harris T. G., Jr. (1998). Industrial timberland: Current situation, holding rationale, and future development. Forest Products Journal, 48, 43-48.

Zinkhan, F. C., Sizemore, W. R., Mason, G. H., \& Ebner, T. J. (1992). Timberland investments: A portfolio perspective. Portland, OR: Timber Press. 